\title{
NEAR-FAULT MINING INDUCED MICROSEISMIC DISTRIBUTION CHARACTERISTICS AND ITS INFLUENCING FACTORS
}

\author{
Shu-ren Wang, Sheng-nan He, Chun-yang Li, Wen-fa Yan, Zheng-sheng Zou
}

Original scientific paper Mining near the fault structure can easily lead to the fault activity and induce serious geological disasters, posing a serious threat to coal mine safety production. To reveal the surrounding rock activity characteristics induced by near-fault mining, taking Qixing Coal Mine in China as the engineering background, the contrastive analysis of the microseismic events in the fault-control area and the mining disturbance area was conducted based on the microseismic monitoring data. From the point of views of seismic parameter $b$ value and focal-mechanism solution, the microseismic event distribution characteristics and the fracture modes in those two areas were analyzed. With the mining area increasing, the evolution characteristics of the microseismic events in the surrounding rock affected by the near-fault structures were verified by using FLAC ${ }^{3 \mathrm{D}}$. We found that $b$ value in the fault-control area was much lower than that in the mining disturbance area, indicating that the possibility of large-magnitude microseismic events was greater in the former than that in the latter. Moreover, the principal stress difference and the elastic energy in the mining area displayed the discontinuity distribution charateristics. The results showed that there were some threshold values making the microseismic event numbers change rapidly with these factors variation such as mining depth, rock strength and initial stress field. The conclusions are of important theoretical and practical value for the similar mining engineering.

Keywords: fault; microseismic monitoring; mining engineering; numerical simulation; parameter analysis

\section{Karakteristike mikroseizmičkih poremećaja izazvanih rudarenjem blizu konstrukcije s greškom i čimbenici koji na njih djeluju}

Izvorni znanstveni članak

Rudarene u blizini konstrukcije s greškom može lako dovesti do aktiviranja greške i izazvati ozbiljne geološke poremećaje, predstavljajući ozbiljnu prijetnju sigurnosti proizvodnje uglja. Da bi pokazali karakteristike aktivnosti koje se javljaju u okolnoj stijeni zbog rudarenja u blizini područja s greškom, uzimajući Qixing ugljenokop u Kini kao tehnički ambijent, provela se kontrastivna analiza mikroseizmičkih kretanja u nadgledanom području $\mathrm{s}$ greškom na osnovu dobivenih mikroseizmičkih podataka. Promatrano sa stanovišta vrijednosti seizmičkog parametra $b$ i rješenja žarišnog mehanizma, analizirale su se karakteristike širenja mikroseizmičkog događanja i načina loma u ta dva područja. Povećanjem područja rudarenja, provjeravale su se karakteristike razvijanja mikroseizmičkih događanja u okolnoj stijeni pod utjecajem obližnjih konstrukcija s greškom primjenom FLAC ${ }^{3 \mathrm{D}}$. Ustanovili smo da je $b$ vrijednost u praćenom području s greškom mnogo niža od one u području nesigurnog rudarenja, što znači da postoji veća opasnost od pojave mikroseizmičkih poremećaja velikog opsega u prvom nego u drugom slučaju. Uz to, razlika u osnovnom naprezanju i elastičnoj energiji u području iskapanja pokazala je karakteristike diskontinuiranog rasprostiranja. Rezultati su pokazali da su postojale neke granične vrijednosti koje su uzrokovale rapidnu promjenu broja mikroseizmičkih pomaka s promjenom faktora kao što su dubina iskapanja, čvrstoća stijene i područje početnog naprezanja. Zaključci su od velike teorijske i praktične vrijednosti za slično rudarstvo.

Ključne riječi: analiza parametara; kvar; mikroseizmički nadzor; numerička simulacija; rudarstvo

\section{Introduction}

When there are fault structures in the mining field, the near-fault mining will lead to the concentration of the mining stress and the elastic strain energy, which often induces the sudden slip and instability of the fault structure and causes serious rock burst or mine earthquake [1]. For examples, these coal mines in China such as Dongtan, Baodian, Huafeng, Muchengjian, and Yima, etc. have experienced the rock bursts. In Czech and Polish underground hard coal mines of the Upper Silesian Coal Basin, Merlebach mine in East France, and Kopanang gold mine in South Africa, the high-energy seismic phenomena are periodically recorded. With the mining depth increasing, the risk and frequency of rock burst or earthquake will become increasingly serious. Due to this kind of disaster with instantaneous characteristics, high energy and magnitude, the damage caused by the rock burst under near-fault mining is more serious. Thus, it is of great significance for safely mining to forecast and prevent the rock burst.

It is extremely complicated and difficult to predict the time, place, region, and source of the rock burst or earthquake, which is still unsolved problem in the world. Since the near-fault mining usually has a potent effect on the stress field nearby the fault so it is essential to monitor the surrounding rock in the vicinity of the fault during the mining or underground excavation for early warning and prevention potential geological hazards [2, 3]. As one of the monitoring methods, the microseismic monitoring technique can record seismic waves released from the rock mass (microseismic events) to obtain the comprehensive information about the disturbed rock mass, which is widely used in the engineering practice $[4 \div 6]$. At present, for the earlier micro-earthquake monitoring, countries such as South Africa, Poland, Czech, Canada, and others have formed the national mine microseismic monitoring network. In China, the great progress has been made in this respect since Mentougou Coal Mine for the first time used the micro-earthquake monitoring in 1959. So it is of importance to research on the distribution and evolution characteristics of the microseismic events induced by near-fault mining based on the former achievements.

\section{State of the art}

With the microseismic monitoring and other technical means, a great deal of research work was conducted on the mining engineering which was affected by the fault structure. For examples, Driad-Lebeau L. et al. proposed that a fault structure in the floor under high stress conditions resulted in a serious rockburst accident in Merlebach Coal Mine in France based on microseismic 
monitoring data [7]. Jiang F. X. et al. divided the faultcontrol rockbursts into two types: increasing and decreasing pressure modes, and pointed out the difference between the two types for risk assessment [8]. Using the Integrated Seismicity System (ISS), Zhang B. H. et al. evaluated the rock mass stability of a fault-control area nearby Dagangshan Hydropower Station [9]. Snelling P. E. et al. explored the relationships in geologic structures, stress field and microseismic events based on the background of Creighton Mine in Canada, and they found that the microseismic events with large energy often occurred in the shear zones near faults [10]. Li S. G. et al. summarized the key parameters inducing dynamic disasters in rock mass and studied their impacts on the reverse faults with different dip angles [11]. Jiang J. Q. et al. found that the fault structure had a significant influence on the stress field by analyzing the stress evolution process in the working face approaching a normal fault with thick overburden rock mass [12].

Throughout the previous work, the research results were mainly focused on the microseismic events and the stress field distributions near the fault structures. However, few studies addressed the comparative analysis of the microseismic events distribution between the faultcontrol area and the engineering disturbance area. Moreover, the sensitive factors affecting the microseismic events during the near-fault mining were rarely reported. So for the early warning and geological disaster prevention, this paper tried to research the different characteristics of the microseismic events distribution and the stress field evolution in the above mentioned two different areas based on the microseismic monitoring data in East-3 mining area of Qixing Coal Mine in China, and then to study the sensitive factors affecting the microseismic activity by using FLAC $^{3 \mathrm{D}}$.

The remainder of this study was organized as follows. In Section 3, the engineering situations, the collecting and processing method of the microseismic monitoring data, and the computational model were introduced. In Section 4, the microseismic events distribution and evolution characteristics based on measured data was analyzed, moreover, the sensitive factors affecting the microseismic activity by using numerical simulation was studied. Finally, some conclusions were given in Section 5.

\section{Methodology}

\subsection{Engineering situations}

The Qixing Coal Mine being located in Heilongjiang Province of China was put into operation in 1973, and the annual output was $2,4 \mathrm{Mt}$. The two mining levels were $-100 \mathrm{~m}$ and $-450 \mathrm{~m}$, and the thickness of the main coal was $2,45 \div 3,60 \mathrm{~m}$, with the dip angle about $10^{\circ}$. The roof and floor of the coal seam were mainly sandstone and siltstone, with poor integrity in part areas. The longwall high-grade general mining method was adopted in Qixing Coal Mine.

As shown in Fig. 1, the depth of the working face in East- 3 mining area was about $550 \mathrm{~m}$, the mining area was about $330 \mathrm{~m}$ long and $160 \mathrm{~m}$ wide, and the stop mining position was about $200 \mathrm{~m}$ away from the open-off cut. The working face was arranged between two normal faults, $F_{1}$ and $F_{2}$. The inclination of each fault was about $70^{\circ}$. The distance of $F_{1}$ was $0 \div 25 \mathrm{~m}$ and that of $F_{2}$ was $15 \div 50 \mathrm{~m}$. Several small faults had been detected in the roadway excavation as well.

\subsection{Collecting and processing method of microseismic monitoring data}

In order to obtain the dynamic information about the mining stress field and fault activity during the mining process, the Canadian ESG microseismic monitoring system was introduced in East-3 mining area of Qixing Coal Mine in Sep. 2013. The hardware part of the system mainly consisted of microseismic sensors, digital acquisition instrument, data transmission network, GPS time synchronization source, ground data processing center, and wireless transmission system.

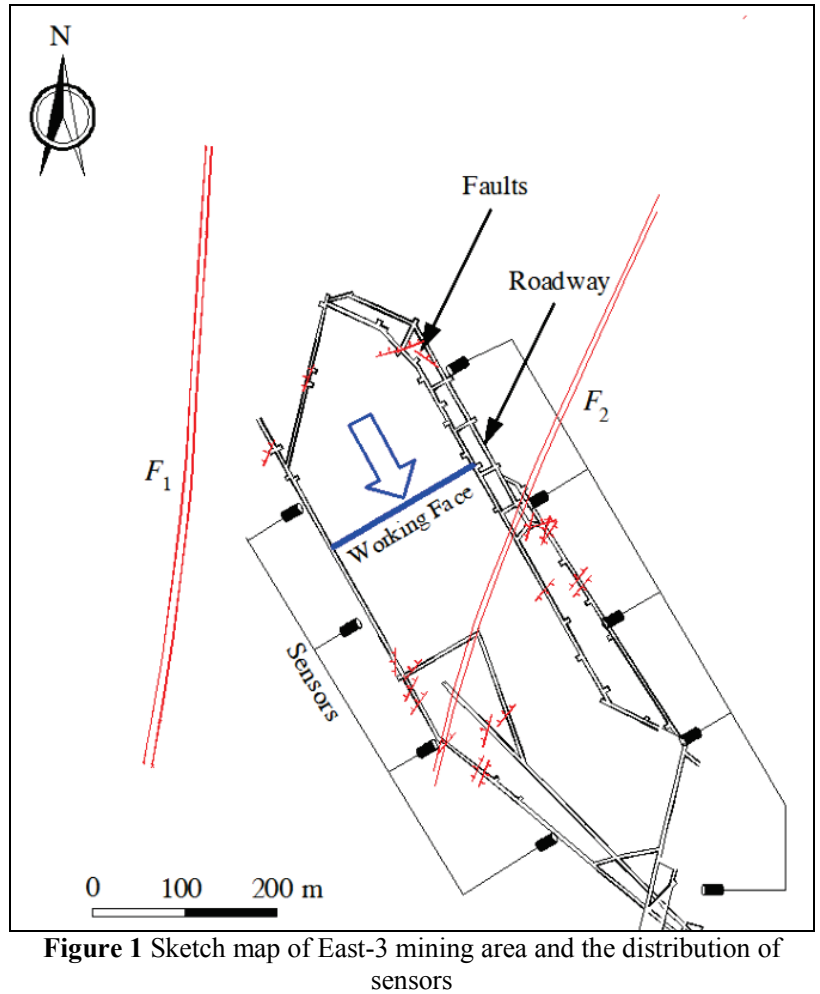

The microseismic events acquisition process: Firstly, the waveform signals of the microseismic events were detected by the microseismic sensors and were transmitted to the digital acquisition instrument. Secondly, the instrument converted the analog signals to digital signals, and packaged them into a packet. Thirdly, these signals were sent to the network switch through the LAN or Remote wireless network. Finally, these signals were imported into the micro-earthquake monitoring system and would be stored in the database after data analysis and positioning.

As shown in Fig. 2, the general processing schemes for the collected microseismic data were to detect, locate and interpret them. In the first, the microseismic events were detected automatically by an advanced algorithm, and then the artificial participation was involved to control the data quality. At last, the microseismic events were precisely located and the source mechanism was determined before a comprehensive interpretation of the results. 


\subsection{Building the computational model}

As shown in Fig. 3, the numerical model was built by using FLAC $^{3 \mathrm{D}}$ and the size of the model was $600 \mathrm{~m}$ long, $600 \mathrm{~m}$ wide, and $300 \mathrm{~m}$ high. The model was divided into 113600 units and 123533 nodes. Considering the physical and mechanical properties, the rock mass in the model was generalized into three rock groups: roof, coal seam and floor. The bottom of the model was fixed and the lateral displacements were limited. However, the top of the model was applied the weight of the overlying strata. Besides, the model material strength was assumed to meet the Coulomb-Mohr criterion.

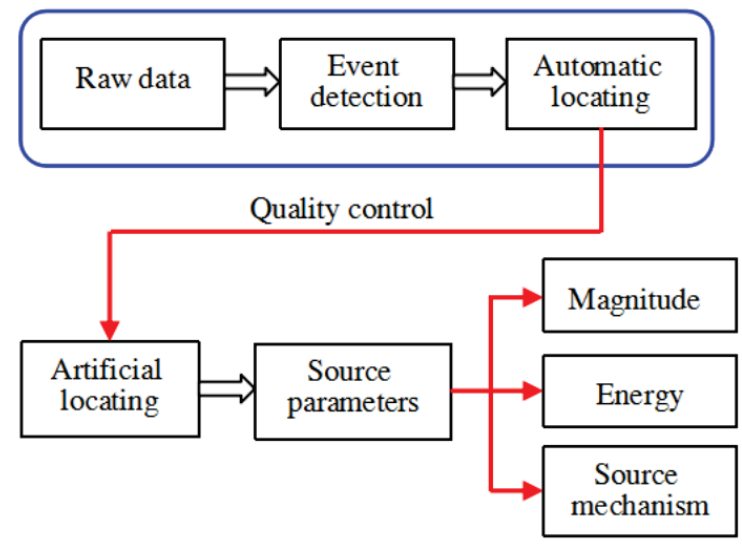

Figure 2 The flow chart of microseismic data processing

The initial stress field of the model was set $\sigma_{\mathrm{H}}=\sigma_{y y}=$ $\sigma_{\mathrm{v}}, \sigma_{\mathrm{h}}=\sigma_{x x}=0,5 \sigma_{\mathrm{v}}$. The displacement and velocity fields were cleared after the whole model was calculated to a balance state. Then the four-step excavation was executed to simulate the mining process (Fig. 3b). The faults, $F_{1}$ and $F_{2}$ were represented by two interfaces whose distribution patterns were observed to the geological reports. The physical and mechanical parameters of the model and two faults were listed in Tabs. 1 and 2, respectively.

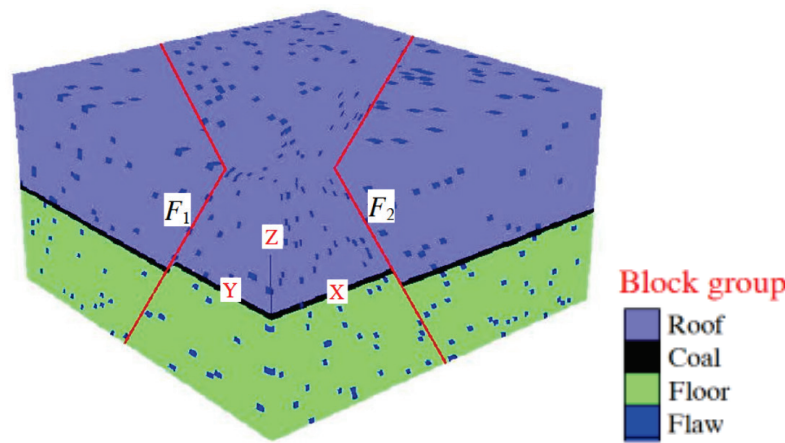

a) 3D numerical model

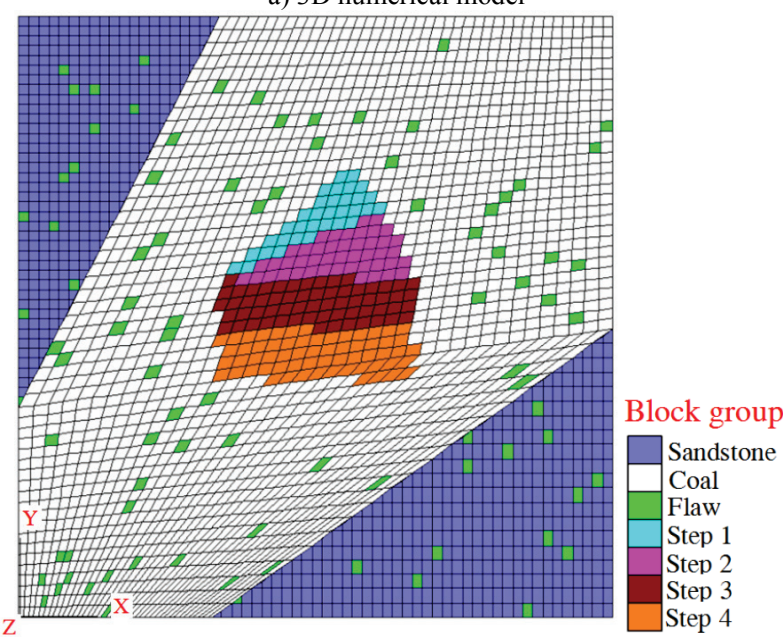

b) Four-step excavation in mining area on $z=2 \mathrm{~m}$ plane

Figure 3 The computational model and the excavation sequence in the mining area

Table 1 Physical and mechanical parameters of the model

\begin{tabular}{|c|c|c|c|c|c|c|}
\hline Groups & $\begin{array}{l}\text { Density } \\
\left(\mathrm{kg} / \mathrm{m}^{3}\right)\end{array}$ & $\begin{array}{l}\text { Bulk modulus } \\
(\mathrm{GPa})\end{array}$ & $\begin{array}{c}\text { Shear modulus } \\
(\mathrm{GPa})\end{array}$ & $\begin{array}{c}\text { Cohesion } \\
(\mathrm{MPa})\end{array}$ & $\begin{array}{c}\text { Friction angle } \\
\left({ }^{\circ}\right)\end{array}$ & $\begin{array}{c}\text { Tensile strength } \\
(\mathrm{MPa})\end{array}$ \\
\hline Roof & 2500 & 4,50 & 1,50 & 3,50 & 45 & 0,10 \\
\hline Floor & 2600 & 6,40 & 2,20 & 5,80 & 48 & 0,50 \\
\hline Coal & 1300 & 4,20 & 1,20 & 1,60 & 30 & 0,05 \\
\hline Flaw & 2500 & 4,20 & 1,30 & 0,80 & 21 & 0,05 \\
\hline
\end{tabular}

Table 2 Physical and mechanical parameters of the faults

\begin{tabular}{|c|c|c|c|c|c|c|c|}
\hline Fault Name & $\begin{array}{l}\text { Strike } \\
\left({ }^{\circ}\right)\end{array}$ & $\begin{array}{l}\text { Dip } \\
\left({ }^{\circ}\right)\end{array}$ & $\begin{array}{l}\text { Displacement of fault } \\
(\mathrm{m})\end{array}$ & $\begin{array}{l}\text { Normal stiffness } \\
(\mathrm{GN} / \mathrm{m})\end{array}$ & $\begin{array}{l}\text { Shear stiffness } \\
(\mathrm{GN} / \mathrm{m})\end{array}$ & $\begin{array}{l}\text { Cohesion } \\
\text { (MPa) }\end{array}$ & $\begin{array}{c}\text { Friction angle } \\
\left({ }^{\circ}\right)\end{array}$ \\
\hline$F_{1}$ & 7 & 70 & 10 & 6,00 & 6,00 & 0,50 & 15 \\
\hline$F_{2}$ & 22 & 70 & 20 & 3,00 & 3,00 & 0,50 & 15 \\
\hline
\end{tabular}

Due to the weak joints and faults, the engineering rock mass always showed strong non-uniformity and nonequal strength characteristics, which were mainly the sources of microseismic events as well. To reflect this feature, a FISH function was written in $\mathrm{FLAC}^{3 \mathrm{D}}$; there were 14000 defective units being set randomly in the computational model to represent the weak parts of the rock. In addition, the microseismic event was the microrupture in rock mass accompanied by the release of elastic energy and the rupture of a unit in the model also represented the release of energy. So the rupture of a defective unit was taken as the criteria for the occurrence of a microseismic event $[13,14]$.

\section{Result analysis and discussion \\ 4.1 Average energy values analysis of the microseismic events in $R_{1}$ and $R_{2}$}

As shown in Fig. 4, to reveal the influence of $F_{1}$ on the microseismic events distribution, the whole monitoring region was divided into two parts, the faultcontrol region $R_{1}$ and the mining disturbance area $R_{2}$. The 
East-3 mining area was initially mined on Nov. 1st, 2013 while the microseismic monitoring system began the continuous monitoring for 150 days from the same day. There were a total of 133 microseismic events occurrence in $R_{1}$, while 1216 microseismic events in $R_{2}$.

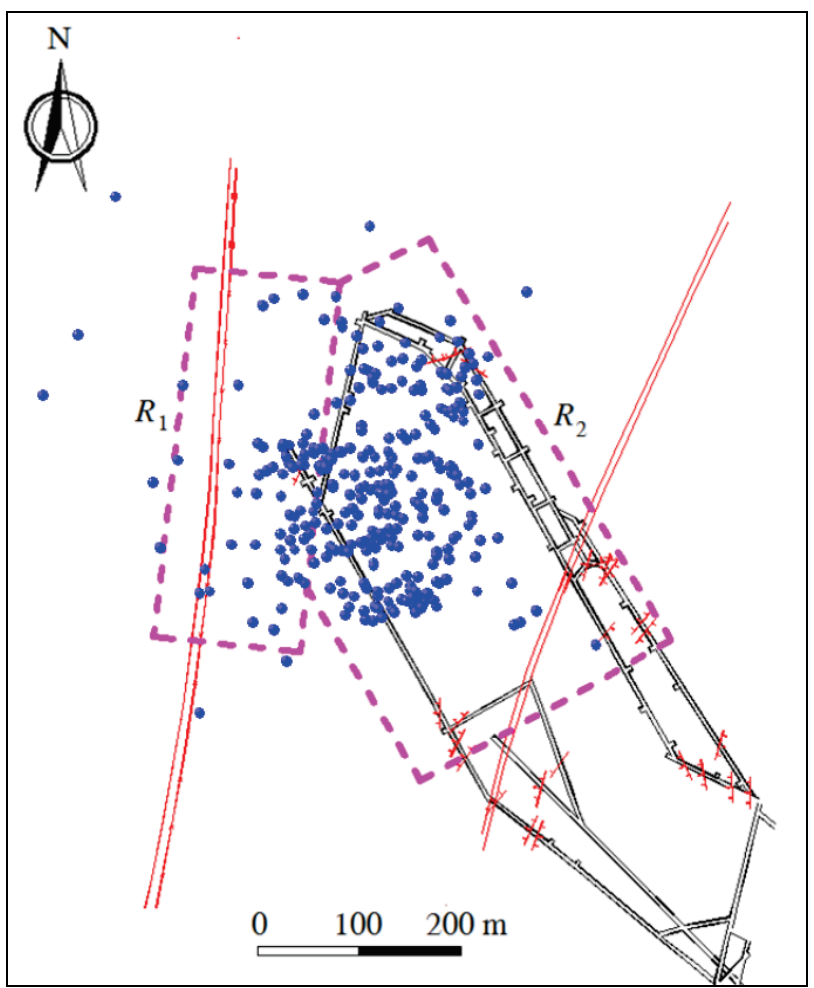

Figure 4 The microseismic event distributions in different regions

In the monitoring period, the moment magnitude and released energy of each microseismic event was calculated by the system instantly. The average energy values of the microseismic events in these two regions were $2,68 \times 10^{4} \mathrm{~J}$ in $R_{1}$ and $1,59 \times 10^{4} \mathrm{~J}$ in $R_{2}$, respectively. The former was $69 \%$ higher than the latter, indicating that there were more larger-magnitude microseismic events in the fault-control area $R_{1}$ than those in $R_{2}$.

\subsection{Different characteristics of parameter $b$ value in $R_{1}$ and $R_{2}$}

In seismicity, the earthquake magnitude and occurring frequency in a region were often regarded to observe to the empirical formula: $\lg N=a-b M$. Where $M$ was the magnitude of the earthquake, $N$ was the number of the earthquakes whose magnitudes were greater than $M, a$ and $b$ were the regional geological parameters [15]. The formula was widely used in the world. Many researchers were interested in the physical meaning of $b$ value and its influence on the temporal and spatial distribution of earthquakes $[16,17]$. In general, $b$ value reflected the stress change levels in the rock mass, and the releasing potential of energy was high if $b$ value was low.

As shown in Fig. 5, the data of microseismic events was fitted in both $R_{1}$ and $R_{2}$ using this formula, where $b$ values were 2,184 in $R_{1}$ and 2,782 in $R_{2}$, respectively. It can be seen that $b$ value in fault-control area $R_{1}$ is lower than that in $R_{2}$ due to the $F_{1}$ fault structure, which indicated that the occurring possibility of the largemagnitude microseismic events in $R_{1}$ was more than that in $R_{2}$. This can be proved by the measured results that the average energy of the microseismic events in $R_{1}$ $\left(2,68 \times 10^{4} \mathrm{~J}\right)$ was much higher than that in $R_{2}\left(1,59 \times 10^{4} \mathrm{~J}\right)$.

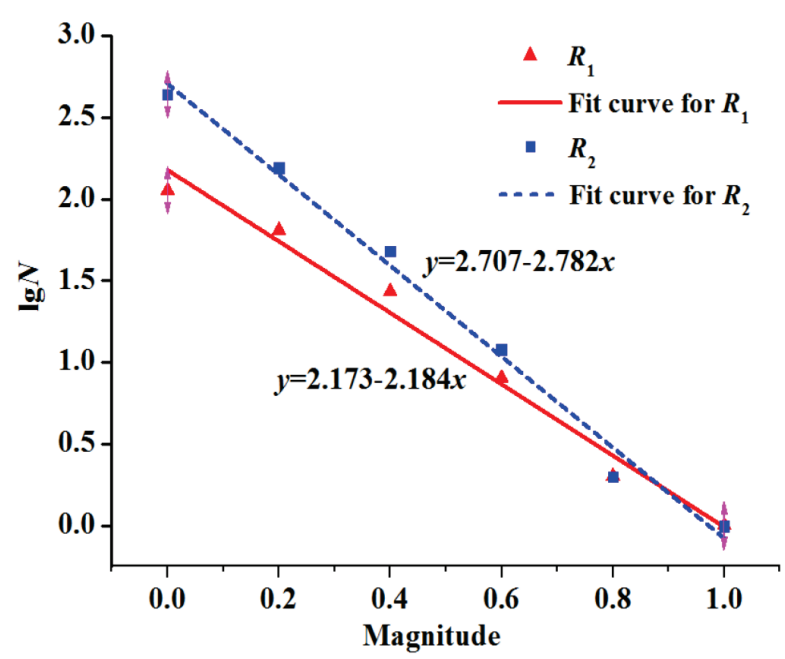

Figure 5 Comparison curves of different $b$ values in $R_{1}$ and $R_{2}$

\subsection{Differences of focal-mechanism solutions and fracture modes in $R_{1}$ and $R_{2}$}

The focal-mechanism solution was widely used to describe the mechanical process in the source area during an earthquake, which was usually interpreted by the so called double-couple model. In this theory, the source area was divided into four quadrants including compression and expansion regions through comparing initial directions of $P$ waves recorded by different sensors $[18,19]$. In order to analyze the failure characteristics of the disturbed rock mass in the fault-control area and reveal its fracture mechanism, the fracture modes of the disturbed rock mass were statistically analyzed.

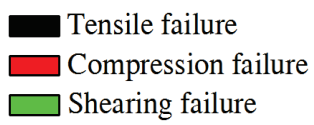

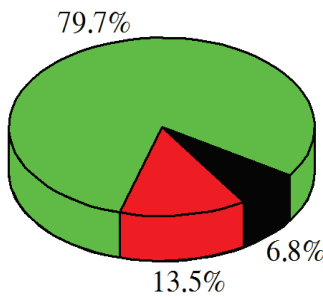

a) $R_{1}$

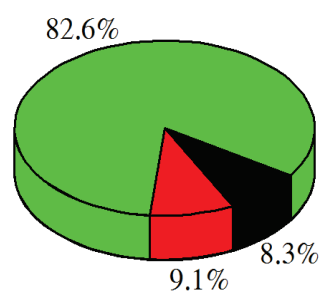

b) $R_{2}$
Figure 6 Pie charts of focal-mechanism solutions in $R_{1}$ and $R_{2}$

As can be seen from Fig. 6, the shearing failure occupied a dominant percentage, as high as $79,7 \%$ in $R_{1}$, followed by compression failure and tensile failure, with $13,5 \%$ and $6,8 \%$ respectively. In $R_{2}, 82,6 \%$ microseismic events experienced shearing failures, accounting for an overwhelming rate as well. However, the proportion of compression failure mode was obviously lower $(9,1 \%)$ while the tensile failure was higher $(8,3 \%)$ than the former ones. It seemed that the rock mass in $R_{1}$ had experienced a high potential of compression failure because there was a relatively high 
compression stress concentration near the fault $F_{1}$ than that in $R_{2}$.

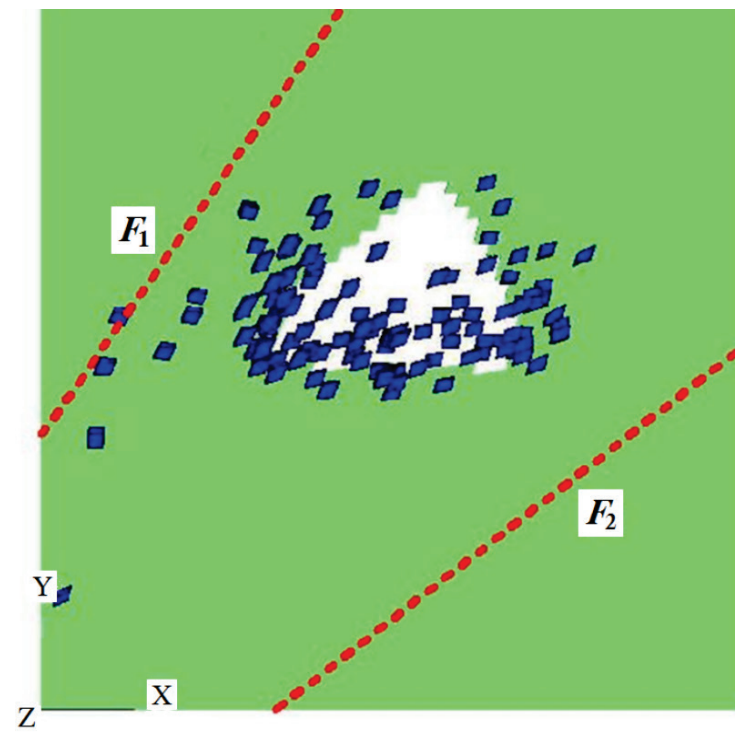

a) The calculation results

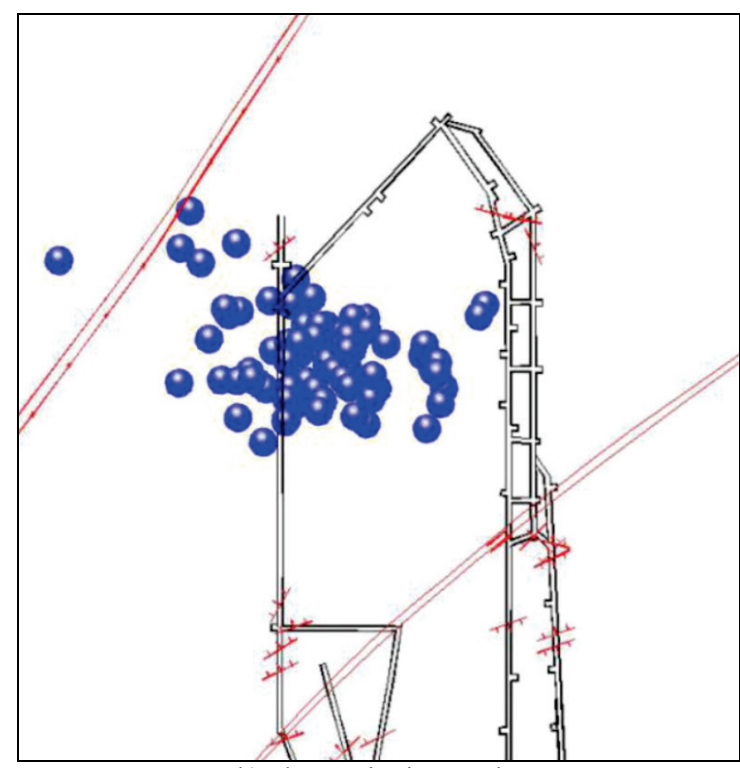

b) The monitoring results

Figure 7 Microseismic events distribution after the $3^{\text {rd }}$ excavation

\subsection{Distribution and evolution characteristics of micro- seismic events}

During the numerical calculation process, the software automatically recorded the information of rupture units (i.e. microseismic events). After the first and second step excavations, the simulated microseismic events were mainly concentrated in the front of the working face and the surrounding rock of the roof, while few microseismic events occurred near the $F_{1}$ or $F_{2}$ normal faults. As shown in Fig. 7, after the third excavation, apart from the ones in the working area like before, a small amount of microseismic events occurred between the left roadway and $F_{1}$ fault (Fig. 7a). It was shown that the disturbance area had influenced the $F_{1^{-}}$ control area $R_{1}$, which could be confirmed by the measured result (Fig. 7a). At the end of the last excavation, with the disturbance area further enlarging, both the calculated and the measured microseismic events accumulated in the $F_{1}$-control area $R_{1}$ (Fig. 8), indicating that $F_{1}$ fault had begun to activate. The numerical and monitoring results coincided with each other, showing that $F_{1}$ normal fault began to activate after 90 days due to the redistribution of the stress field.

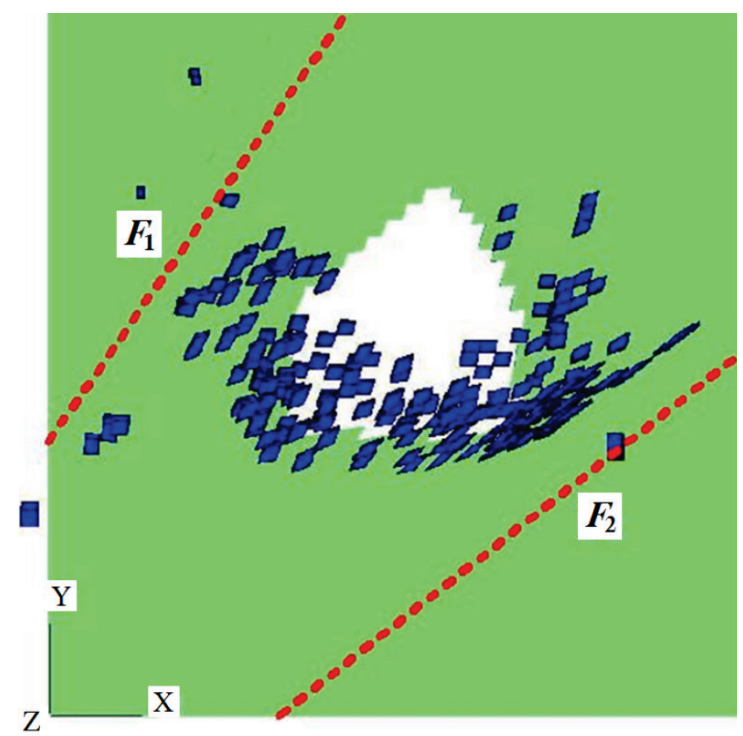

a) The calculation results

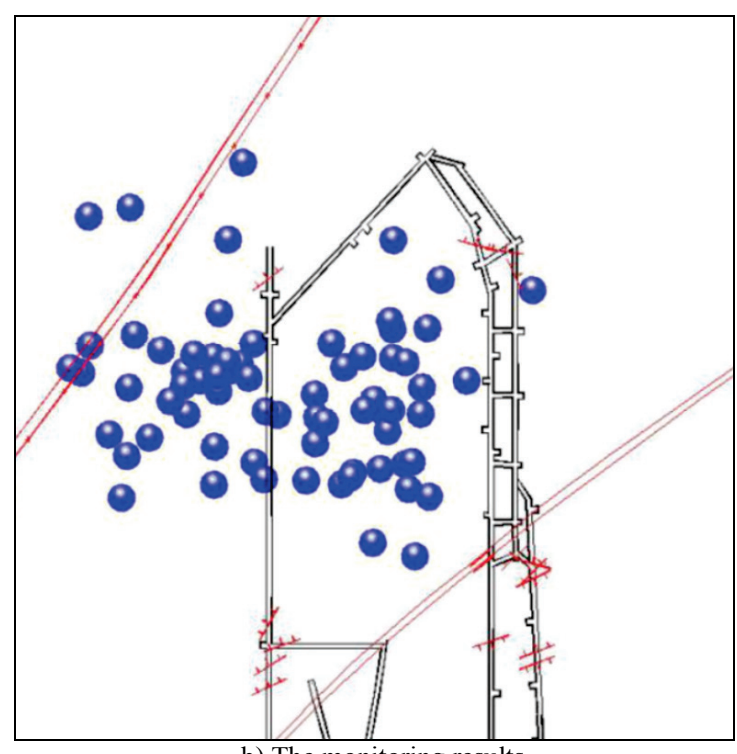

b) The monitoring results

Figure 8 Microseismic events distribution after the $4^{\text {th }}$ excavation

\subsection{Distribution characteristics of the principal stress difference and the elastic energy}

In rock mechanics, the principal stress difference can better present the essence of rock deformation and failure [20], for it can reflect the vertical and horizontal stress synthetically, namely the level of the shearing stress under many complex loading conditions. As shown in Fig. 9, the distribution of the principal stress difference in East-3 mining area after the $4^{\text {th }}$ excavation displayed discontinuous near the two faults. The principal stress difference near $F_{1}$ was lower than that in other surrounding rock mass, which was also obviously lower than nearby $F_{2}$. The decrease of the principal stress difference nearby $F_{1}$ might be due to the active deformation of itself. In addition, the faults also had 
significant impacts on the elastic energy distribution (Fig. 10 ), and the calculation method of the elastic energy can be found in reference [21]. The elastic energy distribution in the vicinity of the two faults also showed discontinuous features: the elastic energy near $F_{1}$ was lower than that in other surrounding rock and nearby $F_{2}$. These characteristics also reflected the loss of elastic energy due to the activation of $F_{1}$ fault.
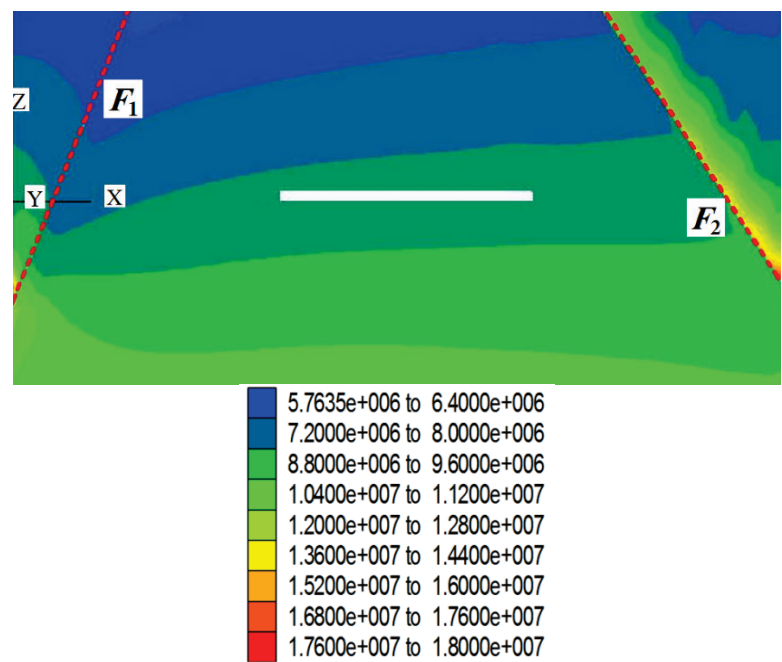

Figure 9 Principal stress differences near the two faults (MPa)

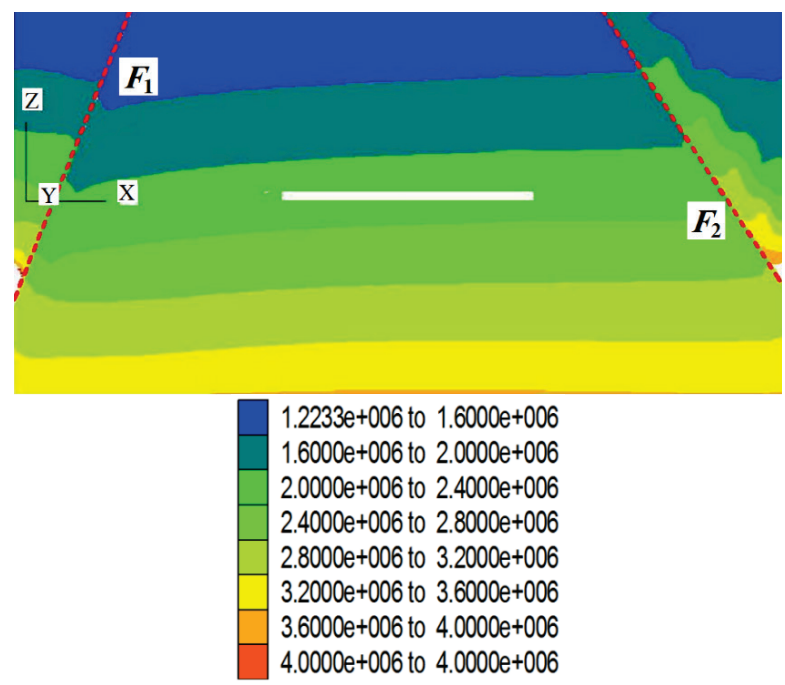

Figure 10 Elastic energy distribution near the two faults $(\mathrm{J})$

\subsection{Sensitive factors analysis of microseismic events}

To investigate the sensitive factors that may affect the microseismic events (ME), the number of microseismic events in different mining stages being as the indicator, the curves were obtained under different working conditions by setting the different burial depths, the different friction angles of the faults and the different stress fields.

It can be seen from Fig. 11, the number of microseismic events displayed an increase trend with the mining depth increasing: it went up slowly in the range of $450 \mathrm{~m}$ and $600 \mathrm{~m}$, and rose sharply after $600 \mathrm{~m}$.

As shown in Fig. 12, the number of microseismic events decreases sharply when the friction angle of the fault was less than $22^{\circ}$ and then decreases slowly.

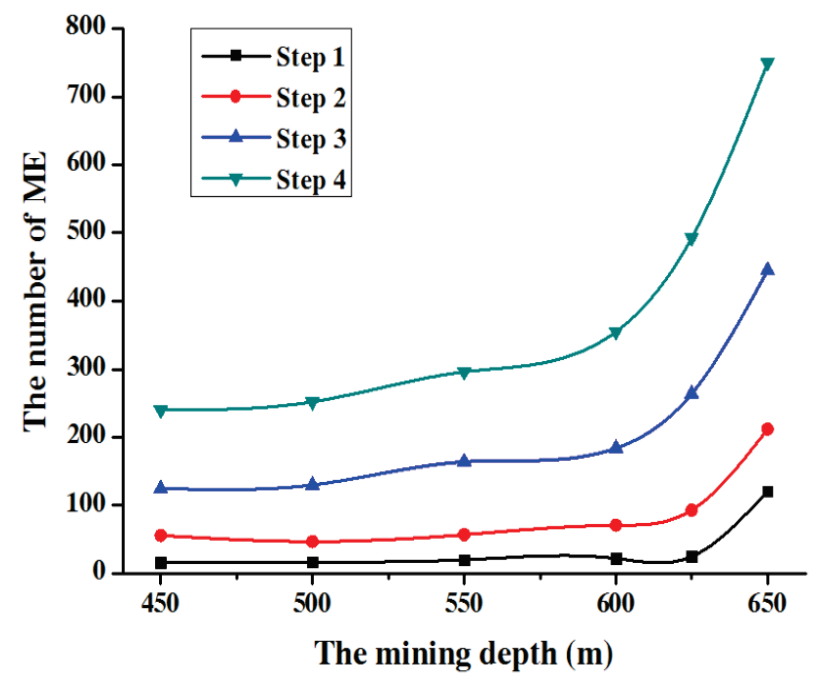

Figure 11 Curves of ME numbers with the mining depth

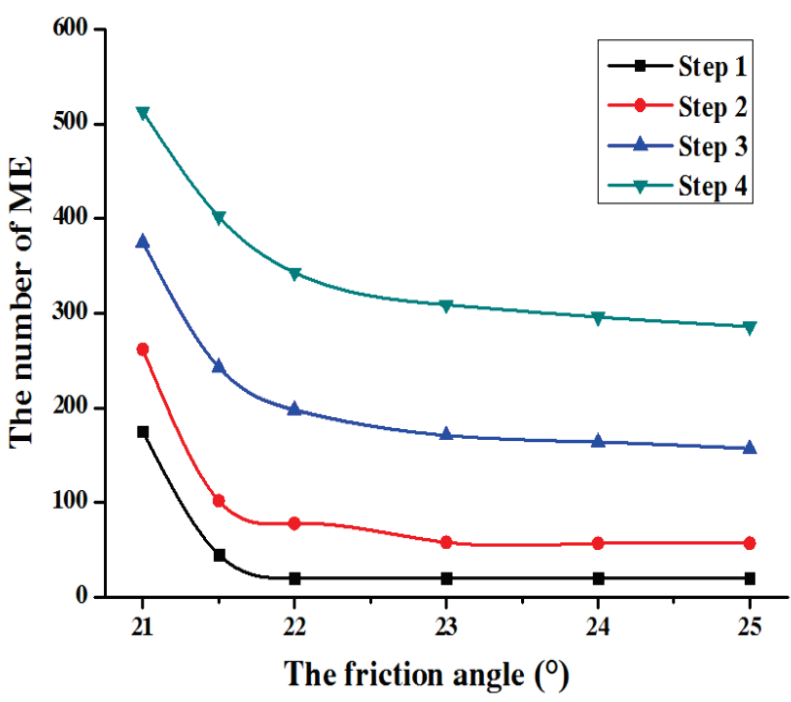

Figure 12 Curves of ME numbers with the friction angle

It can be seen from Fig. 13, with the stress ratio $R=$ $\sigma_{y y} / \sigma_{x x}$ increasing by setting $\sigma_{x x}$ stable and $\sigma_{y y}$ changeable, the number of microseismic events increased gradually before 1,0 and rapidly after that value.

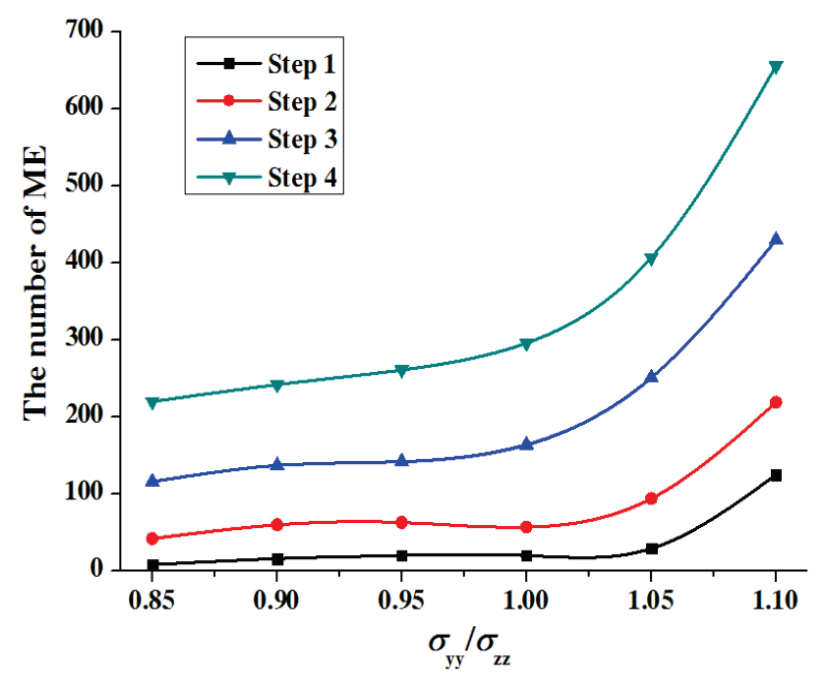

Figure 13 Curves of ME numbers with the stress ratio 


\section{Conclusion}

To reveal the microseismic events characteristics induced by near-fault mining, this study conducted the contrastive analysis of the microseismic events in the fault-control area $R_{1}$ and the mining disturbance area $R_{2}$. From the point of view of seismic parameter $b$ value and focal-mechanism solution, we anlyzed the microseismic event distribution characteristics and the fracture modes in those two areas. Moreover, we built the computational model to study the sensitive factors affecting the microseismic events during the near-fault mining. We finaly achieved the conclusions as follows:

(1) We found that $b$ value in $R_{1}$ was much lower than that in $R_{2}$, indicating that the occurring possibility of large-magnitude microseismic events in $R_{1}$ was higher than the latter. In terms of the focal-mechanism solution, it seemed that the rock mass in $R_{1}$ had experienced a high potential of compression failure because there was a relatively higher compression stress concentration near the fault $R_{1}$ than that in $R_{1}$.

(2) The simulation results verified the evolution characteristics in $R_{1}$ with the mining area increasing and showed the discontinuity distributions of the principal stress difference and the elastic energy nearby the faults. Through the sensitive factors analysis, we found that there were some threshold values for the sharply increasing of the microseismic event numbers with these factors changing, such as the mining depths, the friction angles of the faults and the stress fields.

This study provides a new idea to analyze the microseismic event distributions under the near-fault mining condition, and the results can greatly promote the microseismic monitoring in practice. However, further studies are needed to obtain more important information with large amounts of data increasing by the long time continuously monitoring.

\section{Acknowledgement}

This work was financially supported by the National Natural Science Foundation of China (51474188), the International Cooperative Talent Project of Henan Province (2016GH22), the International Cooperation Project of Henan Science and Technology Department (162102410027), the Doctoral Fund of Henan Polytechnic University (B2015-67), and Taihang Scholars Program. All these are gratefully appreciated.

\section{References}

[1] Zhao, H. J.; Ma, F. S.; Li, G. Q.; Ding, D. M.; Wen, Y. D. Fault effect due to underground excavation in hangingwalls and footwalls of faults. // Chinese Journal of Geotechnical Engineering. 30, 9(2008), pp. 1372-1375.

[2] Jiang, Y. D.; Lu, Y. K.; Zhao, Y. X.; Gao, Z. X. Multiparameter monitoring the stability of rock around roadway while fully mechanized coal face passing through fault. // Journal of China Coal Society. 36, 10(2011), pp. 16011602

[3] Yang, J. L.; Zuo, J. P.; Sun, K.; Meng, B. B.; Lin, X. Insitu observation and numerical analysis of surface subsidence of high working face with multi-fault induced by full-mechanized mining activity. // Chinese Journal of
Rock Mechanics and Engineering. 30, 6(2011), pp. 12161224.

[4] Riemer, K. L.; Durrheim, R. J. Mining seismicity in the Witwatersrand Basin: monitoring, mechanisms and mitigation strategies in perspective. // Journal of Rock Mechanics and Geotechnical Engineering. 4, 3(2012), pp. 228-249. DOI: 10.3724/SP.J.1235.2012.00228

[5] Sun, J.; Wang, L. G.; Tang, F. R.; Shen, Y. F.; Gong, S. L. Microseismic monitoring failure characteristics of inclined coal seam floor. // Rock and Soil Mechanics. 32, 5(2011), pp. $1589-1595$

[6] Wang, S. R.; Li, N.; Li, C. L.; Zou, Z. S.; Chang, X. Instability mechanism analysis of pressure-arch in coal mining field under different seam dip angles. // DYNA. 90, 3(2015), pp. 279-284. DOI: 10.6036/7530

[7] Driad-Lebeau, L.; Lahaie, F.; Heib, M. A.; Josien, J. P.; Bigarré, P.; Noirel, J. F. Seismic and geotechnical investigations following a rockburst in a complex French mining district. // International Journal of Coal Geology. 64, 1(2005), pp. 66-78. DOI: 10.1016/i.coal.2005.03.017

[8] Jiang, F. X.; Miao, X. H.; Wang, C. W.; Song, J. H.; Deng, J. M.; Meng, Fei. Predicting research and practice of tectonic-controlled coal burst by microseismic monitoring. // Journal of China Coal Society. 35, 6(2010), pp. 900-903.

[9] Zhang, B. H.; Deng, J. H.; Zhou, Z. H.; Lv, H. X.; Wu, J. $\mathrm{C}$.; $\mathrm{Wu}, \mathrm{S}$. H. Analysis of monitoring microseism in areas controlled by faults near powerhouse in Dagangshan hydropower station. // Rock and Soil Mechanics. 33, S2(2012), pp. 213-218.

[10] Snelling, P. E.; Godin, L.; Mckinnon, S. D. The role of geologic structure and stress in triggering remote seismicity in Creighton Mine, Sudbury, Canada. // International Journal of Rock Mechanics \& Mining Sciences. 58, 1(2013), pp. 166-179. DOI: 10.1016/j.jijmms.2012.10.005

[11] Li, S. G.; Lv J. G.; Jiang, Y. D.; Jiang, W. Z. Coal bump inducing rule by dip angles of thrust fault. // Journal of Mining and Safety Engineering. 31, 6(2014), pp. 869-875.

[12] Jiang, J. Q.; Wu, Q. L.; Qu, H. Evolutionary characteristics of mining stress near the hard-thick overburden normal faults. // Journal of Mining and Safety Engineering. 31, 6 (2014), pp. 881-887.

[13] Wang, X. B. Numerical simulation of failure processes and acoustic emissions of rock specimens with different strengths. // Journal of University of Science and Technology Beijing. 30, 8(2008), 837-843.

[14] Han, T. C.; Zhang, J. Numerical simulation of acoustic emission for defective rock. // Chinese Journal of Rock Mechanics and Engineering. 33, S1(2014), pp, 3198-3204.

[15] Varley, N.; Arámbula-Mendoza, R.; Reyes-Dávila, G.; Sanderson, R.; Stevenson, J. Generation of vulcanian activity and long-period seismicity at Volcán de Colima, Mexico. // Journal of Volcanology \& Geothermal Research, 198, 1-2(2010), pp. 45-56.

[16] Alvarez-Ramirez, J.; Echeverria， J. C.; Ortiz-Cruz, A.; Hernandez, E. Temporal and spatial variations of seismicity scaling behavior in Southern México. // Journal of Geodynamics. 54, (2012), pp. 1-12. DOI: 10.1016/j.jog.2011.09.001

[17] Grzegorz, M.; Aleksandra, P.; Adam, B. b-value as a criterion for the evaluation of rockburst hazard in coal mines. // 3rd International Symposium on Mine Safety Science and Engineering/ Montreal, 2016, pp. 13-19.

[18] Š́lený, J.; Milev, A. Source mechanism of mining induced seismic events-Resolution of double couple and non double couple models. // Tectonophysics. 456, 1(2006), pp. 3-15.

[19] Li, S. L.; Hu, J. Y.; Zhou, A. M.; Lin, F.; Yu, Z. F. Comprehensive research on character of collapse and fracture of large thick overburden in caving mine. // Chinese Journal of Rock Mechanics and Engineering. 35, 9(2016), pp. 1729-1739. 
[20] Xie, S. R.; Li, S. J.; Huang, X.; Sun, Y. D.; Yang, J. H.; Qiao, S. X. Surrounding rock principal stress difference evolution law and control of gob-side entry driving in deep mine. // Journal of China Coal Society. 40, 10(2015), pp. $2355-2360$

[21] Sun, Z. W.; Dai, J.; Yang, C. M.; Yang, J. F. Elastic energy criterion of rockburst in roadway and coal face of mine. // Journal of China Coal Society. 32, 8(2007), pp, 794-798.

\section{Authors' addresses}

\section{Shu-ren Wang, Ph.D., Professor}

(Corresponding author)

1) International Joint Research Laboratory of Henan Province for Underground Space Development and Disaster Prevention, Henan Polytechnic University,

2) Opening Laboratory for Deep Mine Construction, Henan Polytechnic University,

3) School of Civil Engineering, Henan Polytechnic University, Postal address:

2001 Century Avenue, Jiaozuo, Henan Province, 454003, China

E-mail: w_sr88@163.com

\section{Sheng-nan He, B.Sc., Postgraduate}

School of Civil Engineering, Henan Polytechnic University,

Postal address:

2001 Century Avenue, Jiaozuo, Henan Province, 454003, China

E-mail: 704543479@qq.com

\section{Chun-yang Li, B.Sc., Postgraduate}

School of Civil Engineering, Henan Polytechnic University, Postal address:

2001 Century Avenue, Jiaozuo, Henan Province, 454003, China

E-mail: lcykcy@163.com

Wen-fa Yan, M.Sc., Senior Engineer

Anhui Wantai Geophysical Technology Co., Ltd.

Postal address:

No. 1 Shuoguang Road, Baohe District, Hefei, 230011, China

E-mail: 455256804@qq.com

Zheng-sheng Zou, Ph.D., Professor

1) International Joint Research Laboratory of Henan Province for Underground Space Development and Disaster Prevention, Henan Polytechnic University,

2) Opening Laboratory for Deep Mine Construction, Henan

Polytechnic University,

3) School of Civil Engineering, Henan Polytechnic University, Postal address:

2001 Century Avenue, Jiaozuo, Henan Province, 454003, China

E-mail: zouzs@hpu.edu.cn 